\title{
Scarborough based study on bodies' affective capacities
}

\section{Gunjan Saxena}

Faculty of Business, Law and Politics, The University of Hull

\begin{abstract}
This paper conceptualises leisure-seekers' sociality using Deleuze and Guattari's framework of Body without organs (BwO). Data, collected in Yorkshire's coastal town of Scarborough, indicate how the 'beach' acts both as a magnet and a protective shell for a whole gamut of 'intimate social microcosms'. Overall, the value of this study lies in its illustration of bodies' affective capacities and in particular visitors' agency in creating new possibilities for perception and experience of tourist sites. In doing so, it urges tourism studies to engage with how leisure-seekers' bodies enact multiple sensibilities, become 'bodies without organs' without determinate form, in the process of experiencing a locality and (re)imagining its place in their lives.
\end{abstract}

Key words: Deleuze and Guattari, body without organs, beach, leisure seekers

"A Body without organs is not an empty body stripped of organs ... The Body without organs is not a dead body but a living body all the more alive and teeming once it has blown apart the organism and its organisation ... The full body without organs is a body populated by multiplicities' (Deleuze \& Guattari, 1987, p. 30).

(C2017, Elsevier. This manuscript version is made available under the CC-BY-NC-ND 4.0 license http://creativecommons.org/licenses/by-nc-nd/4.0/

\section{Introduction}

This paper looks at leisure-seekers' nuanced engagement with the place and the sense of intimacy, affinity and belonging they experience towards others within the context of the beach. Prasad (2012) argues that the sentiment of camaraderie within the tourist space results from:

“. . . encounters and community formation, seeing one's affectations in others and vice versa. Familiarity rejects the notion of authenticity, because it accompanies the dissolution of the individual in favour of the group. It is a thickening of feeling . . . which bonds dissimilar (yet familiar) bodies into a loosely conceived 'tribe"'(p. 354).

With such affective bonding comes "a temporary loss of the everyday self, and everyday consciousness, in place of which emerge dream-like states where the individual explores his / her emotional and experiential capacity ..." (Canniford, 2011, p. 599). However, these affective processes are difficult to theorise, let alone represent (Thrift, 2007). Indeed, research remains scarce on how leisure-seekers mediate their sense of belonging with a place, approximating a 'home-like' attachment with its facets and the populace present therein through customising, subverting, and re-interpreting its meanings. Also, as Hough (2011 points 
out, their close and long-term ties with the local society are often overlooked in favour of overriding fixed identities defined by a priori categorical distinction between hosts and guests.

Further, whilst marketing and consumer behaviour researchers have long recognised the appetite of consumers to co-produce (see Cherrier, 2007; Firat et al., Kotler, 1986) there is scant research on their extended role in the marketplace, particularly as co-creators of experiences at a site. Few studies look at simultaneously playful and entrepreneurial consumer attributes as they select, (re)interpret and reject elements from a profusion of product / service offerings at a destination. Thus the aim of this paper is twofold: i) uncover the manner in which actors perform and narrate particular identities and negotiate ways of being together with (dis)similar others in tightly packed places of leisure rife with atypical affects; and ii) assess their role in (re)assembling / (re)scripting the place through imagination and cunning. In the context of beach-based leisure experience, as Löfgren (1999) observes, vacationing, despite being a mass phenomenon, can still be very personalised - "conducted within confined space and tailored to one's personality and desires" (Hazbun, 2010, p.207). The beach, as a distinctive holiday spot, presents a unique opportunity to explore how actors enact multiple identities which provide them the locus for 'soaking up' the locality and (re)imagining its place in their lives. At the same time, as Munt (2015) observes:

". . . beaches are also microcosms of morality, as manners dictate what can and cannot be done in the name of freedom, and tourists, with their picnics, deck chairs and mobile music create simulacra of home" (p. 11).

In this sense, the focus of the paper is on place meanings that are created by consumers, independent of the system of place production and resulting from "existing consumer knowledge, travel history, preferences and motivations, previous experiences, and the availability of interpretative information" (Young, 1999, p. 385). Moreover, given the growing emphasis on considering ". . . vacationing as a cultural laboratory where people . . . experiment with new aspects of identities" (Löfgren, 1999, p. 6-7, cited in Franklin \&Crang, 2001), this study looks at how the interplay between people's fluid identities renders and (re)configures a locality.

In examining the beach based holiday experience, Deleuze and Guattari's framework of $\mathrm{BwO}$ is applied as it decentres attention from individuals towards assemblages (containing a flow of affects - or bodies' capacities to affect and be affected by their relations to other bodies, things and abstractions) which enables a richer reading of multisensory consumption experiences. The study focuses on beach based holiday experience which offers an escape from 'the strictures of the self' into a zone of pure intensity, or immanence. The plane of immanence can be defined as boundaryless, smooth domain without constitutive divisions and characterised by formless, self-organising processes of affect (Mullarkey, 2006). Yet, the beach is not only smooth and deterritorialised space, but also striated and territorialised filled with a host of normative performances and expectations that inhibit the undoing of bodies. Striated spaces (e.g. arranged according to gender, class and race) are hierarchical, ruleintensive and confining (Tamboukou (2008). Thhe value of using BwO [mentioned extensively in Anti-Oedipus(1984 / 1972), A Thousand Plateaus (1987) and in Deleuze's (1969 / 1990) The Logic of Sense] as a conceptual lens lies in the fact that offers an ontological basis for 
conceiving a set of practices and tactics that seek to disrupt and undermine fixed identities to which tourists are consigned.

In section 2, I further underline how BwO embodies intensities (which Deleuze, 1994 describes as elements that are virtual, at the limits of perception, yet real) and encounters that take precedence over identity and the precincts of the self. Following a discussion on the study context and methodology in section 3, . empirical findings are presented in section 4 that contain a critical reflection upon implications arising from considering an inclusive view of the 'body' to " . . . be anything; it can be an animal, a body of sounds, a mind or an idea" (Deleuze 1988, p. 127). The emphasis is on how BwO, existing outside any determinate state, is infused with affective capacities and creative potential required to set in motion transgressive happenings. Section 5 brings the discussion to a close by underlining how BwO - “. . o opposed not to the organs but to organisation of organs called the organism" (Deleuze \&Guattari, 1987, p. 158) advances understanding into leisure-seekers' fluid identities - 'in a constant process of becoming'(or flux) - and their creative enterprise in spawning distinctive place uses and meanings.

\section{The Body without Organs (BwO)}

Broadly, studies on holiday-making at mass destinations often approach the phenomenon in a negative tone with scarce attention to the emotionality leisure-seekers enact and experience, resulting in much bias and inaccurate comprehension of its scope (Boorstin, 1964; Poon, 1993; Turner and Ash, 1975). Yet, mass segments are ". . . not mere puppets of the producer; rather, they customise the behavioural and spatial content of their trips" (Vainikka, 2013, p. 280). Thus mass tourism has become "more de-differentiated, esoteric and individualised activity" (Mowforth and Munt (2009, p. 136). Even in the context of beach-based tourism, vacationing, despite being a mass phenomenon, can still be very personalised as visitors tailor it to their personality and desires Löfgren 1999; Hazbun, 2010).

Further, there is growing emphasis on including mundane types of leisure activities (e.g. on the beach or resorts) that centre on "producing social relations rather than consuming places" (Haldrup \& Larsen, 2003, p. 24). In fact, Obrador-Pons (2003) offers the "dwelling metaphor' to draw attention to the multifarious manner in which tourist bodies dwell in a setting and how through the agency of their 'body' dismantle imposed objectifications to seek alternative ways of being. This paper builds upon this argument by considering "a vocabulary of affect" (Little, 2010, p. 7) as means to capture varied and intimate entanglements leisureseekers encounter in their visits. The emphasis is on the immanent body that offers possibilities for not only challenging the notion of stable and discrete individuality and a clear-cut divide between one's self and the world, but also the dissolution of the boundary between selves. Deleuze \& Guattari (1987) contend:

"Is it really so sad and dangerous to be fed up with seeing with your eyes, breathing with your lungs, swallowing with your mouth, talking with your tongue, thinking with your brain, having an anus and larynx, head and legs? Why not walk on your head, sing with your sinuses, see through your skin, breathe with your belly?" (, p. 150-151).

Such an ontology enables an insight into how "one ceases to see organs as being constituent parts of a hierarchical organism" (Hansen, 2010, p. 84). Instead, through immersing in a flow 
of intensities, one acquires the capacity to bring about change and experience a change in personhood as a result of the influence of other material bodies in ". . . an emotional space of belonging together" (Waitt \& Duffy, 2010, p. 458). Within this context, it is worth mentioning Veijola et al.'s (2014) call to welcome the 'untidy' guests who can stir things up and “. . . give an unexpected twist to the social situation" (p. 19). Indeed, embracing "messiness of hospitalities in tourism" (ibid) opens up radically different ways of imagining and enacting alternative socialities and recognising leisure-seekers' role in co-creating affective assemblages of tactile, emotional and communal encounters.

\subsection{Affective assemblages}

For Deleuze and Guattari (1987) a body in itself exists only through its external connections and affects. It is of consequence when:

"... we know what it can do, in other words, what its affects are, how they can or cannot enter into composition with other affects, with the affects of another body" (p. 257).

From this perspective, affective assemblages can be understood as preceding and exceeding the logic of identity and order or as Deleuze (1991) posits: "Why should our bodies end at the skin?" (p. 178). They are heterogeneous, decentred and ephemeral - "product of multiple determinations that are not reducible to a single logic" (Ong \& Collier, 2004, p. 12) - and are constantly emergent - “. . . not always involve new forms, but forms that are shifting, in formation, or at stake" (ibid). Basically, assemblage thinking enables a reading of actors' sociality as a compound of collectivities "drawn together at a particular conjuncture only to disperse or realign, and the shape shifts according to the terrain and the angle of vision" (Li, 2007 , p. 265). Also, it allows the mapping of social and subjective modalities, capture / comprehend "individual, interior spaces" (Ringrose, 2011, p. 600) comprising of affective energies that underlie complex desires and relational bonds. Mostafanezhad (2016), in her work on volunteer tourism, applies the notion of assemblages to examine the collective and affective capacities of tourists in mobilising humanitarian initiatives. Broadly, affective assemblages as social formations are not:

“... reducible to the affections or perceptions of an individual subject ... [are ] a linked, hybrid field of flesh and accompanying objects, rather than a series of individual bodies, intersubjectively linked ..." (Thrift, 2008, p. 116-276).

This implies that the constancy of the assemblage escapes consignment to discrete homogeneous categories and cannot be constricted a priori to a single hue or process due to a collage of ties, desires and affects bodies generate. However, the presence of a multiplicity of dimensions - e.g. routes, momentum and spaces - can either enable or block certain becomings (Deleuze \& Parnet, 1987; Ringrose \& Renold, 2014). For instance, assemblages, guided by a stratified, centralising logic act to produce, organise and stratify bodies. Whilst striated assemblages correspond with the notion of molar - "lines of rigid segmentarity" (Deleuze \& Parnet, 1987 (p. 124-125), smooth i.e. molecular becomings (comprising of actors' subjective emotions and beliefs) are characterised by "supple lines of segmentarity" (ibid). Still, a molar, stratified body remains a multiplicity (albeit a disciplined one) entangled in intersecting lines of becoming (Massumi, 1992). However, it is anti-linear molecular practices or lines of flight (enabling an escape from binaries) that destabilise structure and design through 
re/deterritorialising flows and movements which penetrate and glide between rigidities and erase the edges traced by molar segments.

Deterritorialising flows can be equated with the opening up of possibilities and dismantling of strictures followed by reterritorialising process of recreating what has been taken apart (Saxena, 2015). Thus affective assemblages embodying varied social-culturalmaterial connections and molar / molecular tides afford an insight into how bodies / subjectivities are experienced and negotiated vis-à-vis social and natural environments creating the substrate that delineate actors' capacities and limits. Apart from a body's affective capacities, Deleuze and Guattari are keen to emphasise its faculties in experimenting and desiring which influence and determine 'what (else) can a body do'. Beach-users' bodies (i.e. identity), understood this way as embedded in affectivities, multiplicitous desires and subjectivity - "constituted in constant relation to other bodies and things (i.e. social, material and semiotic) ..." (Renold \&Ringrose, 2011, p. 393) - can be envisaged in a continual state of becoming. Hence in reading how they seek "creative entry points into local communities" (Richards and Marques, 2012, p. 9) in the process of co-creation of experiences, I draw upon Deleuze and Guattari's notion of 'becoming multiple' which implies that the body is destratified from the prevailing order and infused with a cluster of intensities operating on the plane of immanence (i.e. smooth space).

\subsection{Becoming-multiple}

Becoming-multiple can be considered to correspond to the process of co-creation in the sense that it enables the mapping of the 'fluctuations of the self' (e.g. peripatetic nature of leisureseekers' profiles and desires) that superimpose additive and differentiated meanings on a place. Deleuze and Guattari (1987) implore bodies to:

"move between things, establish a logic of the AND, overthrow ontology, do away with foundations, nullify endings and beginnings ... practice pragmatics (p. 25)

Becoming multiple then entails an unhinging of existing beliefs and order and ushering in new thinking and desires that extend in multiple directions simultaneously. However, it does not imply that bodies are fragmented, but hang together as assemblages stocking unbridled competencies emanating from:

“. . . an impersonal rush of liquid flows. These flows oscillate between the amorphous and the polymorphous, the shapeless coming undone of the ... multiplicitous becomings ... (Haines, 2011, p. 107).

In considering 'multiplicitous becomings' underlining actors' creative capacities and intensities, Deleuze and Guattari frame $\mathrm{BwO}$ as 'an immanent field of desire'. In fact, desire is regarded as the harbinger of connection and movement enabling the passage of bodies from one experiential state to another (Deleuze \& Guattari, 1977 / 1987). Actors as desiring machines - "fuelled by experiences and by the products and by-products that they themselves produce" (Tuck, 2010, p. 640) - connect with each other to either activate or disrupt flows in an assemblage. As desire accounts for the unpredicted turns, unsettling of plans and unintended courses of action, Deleuze and Guattari (1990) propose that "desiring-machines continually break-down as they run, and in fact only run when they are not functioning properly ... (p. 
31). The epistemological value of Deleuze and Guattari's malfunctioning desiring-machines lies in the opportunity they afford in conceiving visitors' agency as capable of destabilising or deterritorialising fixed meanings and engendering novel ways of experiencing places.

Further, as an identity-producing device, desire is the multiplicity that is "irreducible to any sort of unity" (Deleuze and Guattari, 1977, p. 42). Indeed, Deleuze introduces the concept of 'rhizome' to indicate multiple courses desire embarks upon to produce especial affects and a range of rhizomes. In botanical terms, a rhizome is a horizontal stem that sends out roots from nodal points, each of which can become a new plant should the rhizome be severed" (Bazzul \&Kayumova, 2016, p. 288-289).Unlike arborescent (tree-like) structures ordered hierarchically in branches and seeking to territorialise through discourse and activities that reduce all relations to a single root, the rhizome with "neither beginning nor end, but always a middle (milieu) from which it grows and which it overspills" (Deleuze and Guattari (1987, p. 21).enables a body's relational potential to be grasped in a continuous state of becoming with the capacity to form multiple relations simultaneously (Malins, 2004). Thus thinking rhizomatically acknowledges that a body has multiple potentials and meanings - (routes as opposed to roots) - dependent upon and resulting from the connections it forges with other bodies and the assemblages it forms (Massumi, 1992).

Applying the rhizome logic to understand leisure-seekers' tactics of place-making allows an appreciation of multiple trajectories of consumption and stories / perceptions of place as affects in a rhizomatic flow. The meanings they imbue upon a place result from what they 'do' in a locality and its faculty to either fleetingly or more concertedly produce lines of flight that liberate desire and open up incessant (re)imaginings of a place and "vectors" of possible becomings" (Deleuze \&Guattari, 1987, p. 19). In this sense, their agency (i.e. what they can do) is no longer an attribute of a body, but derives from re /deterritorialising flows of affect between bodies, experiences and events that determine its capacities and limits.

In general, the theoretical value of $\mathrm{BwO}$ lies in the conduit it provides to comprehend actors' agency as a series of bodily activities immersed in ongoing flows and the capacity of "fully sensuous participative body" (Matteucci, 2014, p. 30) in realising different becomings. Neu et al. (2009) explain how:

“. . we are caught between our earthly, existing and sometimes unhealthy bodies and the bodies that we want to be: dynamic bodies, immortal bodies, bodies that flow, and bodies whose flow is unimpeded or uninterrupted. These (unreal) bodies one could refer to quite simply as "Bodies without Organs" (p. 322).

Hence the process of becoming $\mathrm{BwO}$ is a way of stealing the body from the strata to engage with visceral, ephemeral lines of flight that underline how bodily affects and flows, differentially lived and experienced, define the emotional attachment and connectivity actors form with a place. In arguing in favour of unfastening the grip of normative arrangements on the body, my emphasis is on inviting research to consider the 'in-between' spaces where BwO as 'multiplicities' thrives providing an insight into actors' creative agency resulting from and inherent in the "ceaseless movement - the "and-and-and-and ..." of the rhizome" (Garoian, 2013, p. 141) - in the (re)making of a place. I now present the study context outlining the profile of the town of Scarborough where the empirical investigation was carried out followed by a discussion on research methodology. 


\section{Study Context}

\subsection{Profile of Scarborough}

The coastal town of Scarborough (see Figure 1), situated in the Borough of Scarborough that covers an area of approximately 81,000 hectares in the county of North Yorkshire, is a traditional seaside resort. Overall, the corporate vision of the Scarborough Borough Council (which is also responsible for the management of Scarborough's two neighbouring towns: Filey and Whitby) is to achieve the renaissance of the North Yorkshire Coast by 2020 through creative and digital economy to complement the income from the tourism sector. Tourism is an integral part of Scarborough's economy as the town continues to remain among the top five most popular destinations in the UK for domestic visitors despite the decline in demand for seaside holidays which constitute the town's bread and butter (CFE, 2015). Annually, it is estimated that some 1.62 million visit the town for a holiday trip accounting for more than $£ 300$ million spend, which is higher than other popular locations, including the Isle of Wight, Brighton, Bournemouth (SBC, 2011). In general, eight five percent of tourists to the region are repeat visitors who form strong core market and are drawn by the appeal of the countryside and a feeling of nostalgia (O'Connor et al., 2010). In Yorkshire, the Borough hosts the highest proportion of staying visitors, accommodating $22 \%$ of all overnight visitors (SBC, 2011).

In recent years it has experienced growth in day visitors along with the conference and business tourism trade and weekend breakers. Further, the inaugural Tour de Yorkshire cycle race (created as part of the legacy of Yorkshire's hosting of the opening stages of the Tour de France in 2014) generated an additional $£ 50$ million in 2015 in the region (YEP, 2015). This event, engendering innovative practices and assemblages, rebuts the assessment that there is an absence of economic alternatives within English seaside resorts' (see Agarwal 1994). Overall, the contribution of domestic visitors to the town is substantial as out of a total of around $£ 522.4$ million spent on trips to the borough in 2014 by overnight and day visitors, 57 per cent of this expenditure was made by domestic staying visitors and 39 per cent by day visitors as opposed to only 4 per cent by overseas staying visitors (Scarborough, 2015). There has been a gradual increase in revenue generated by the day tripper segment to the town. According to Great Britain Tourism Survey (GBTS) just under 6 million tourism day trips were made to the borough in 2014 recording an increase in expenditure per head by four per cent (ibid). One of Scarborough's strongest selling points is its attractive landscape and dramatic coastline which has the potential to generate critical mass and momentum in investment through proactive and targeted marketing and re-branding (SBC, 2005).

The South Bay in the town can be described as a seafront entertainment strip comprising of amusement arcades, fish and chip shops and souvenir outlets. The provision of enhanced yachting facilities at the harbour and significant investment in the public realm (e.g. better lighting, seating, cafés and restaurants) has not only provided opportunities for attracting higher value tourism to the town, but resulted in the growth of vibrant early evening economy (SBC, 2006). In contrast, the North Bay, the wilder of Scarborough's two beaches, has a rugged feel and is popular with surfers. Together, the two localities (where the empirical investigation was carried out) are equally popular with people who live in the vicinity and who take pride in "the sea and the countryside on your doorstep"(Hughes-Morgan, 2009). The data offer valuable 
insights into beach-users' sociality, the unique ways in which their social fields - 'leaking out on all sides' (see Deleuze, 2006) - are constituted through 'the literality and singularity of human becomings" (Biehl \& Locke, 2010, p. 318). For Deleuze (2006) 'leaking out' implies escaping the status quo and stable identities to experience new ways of living and thinking. 
Figure 1: Location Map of Scarborough

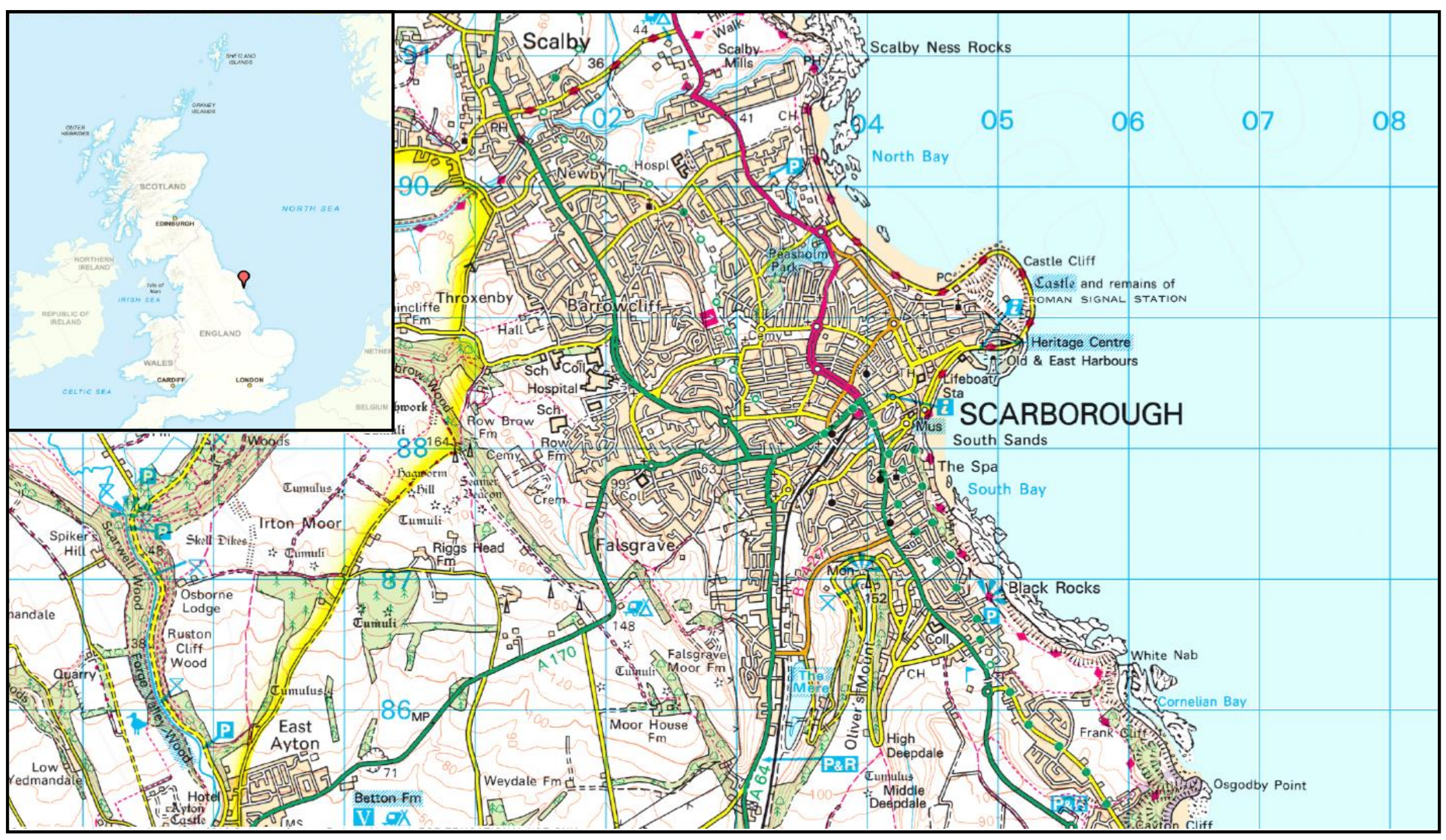

Source: Crown Copyright, Digimap. 


\subsection{Research Methodology}

In order to capture actors' narratives and their subjectivity as 'becoming' - e.g. the immanent fields they fashion that constantly (re)configure and are un /re done by their desires and becomings (Collier \&Ong 2005) - qualitative methodology was adopted in this study. Mainly, the data were derived from two sources: i) sixty face-to-face interviews (each lasting up to 15 minutes) conducted at South and North Bay (30 at each site) in the peak months of May and June, 2016; and ii) fieldwork which involved spending time in the setting and making firsthand observations of leisure activities and the interface taking place between beach users. The interview schedule incorporated six different types of questions (after Patton, 2002), namely: i) demographic (such as age, education, and occupation) to build a profile of the person being interviewed; ii) behavioural which focused on visitors' travel patterns (e.g. number of trips taken in the UK) and how they spend their leisure time; iii) opinion and values-based designed to understand their experience on the beach and their perceptions of other users ; iv) knowledge-based to inquire about visitors' familiarity with the town; v) feelings-related that endeavoured to elicit emotional responses from them about their experiences; and vi) sensory to understand their corporeal involvement with the area based upon what they have seen, heard, touched, tasted and smelled.

In particular, following Deleuze and Guattari's concept of becoming, my emphasis was on observing how leisure-seeking bodies unfolded through interchanges with others as they discussed their experiences and perceptions without following a conscious path, plan or logic - i.e. enter a rhizome. The approach enabled an insight into how actors narrate their identities - in a constant, fluid process of change and transformations - as they (re)claim / reassemble a place by destabilising molar forms and relations that organise and structure bodies, experiences and histories (Jackson, 2010). The raw data (collected from the interviews and participant observation) were organised into readable narrative descriptions with major themes, categories, and illustrative case examples extracted through content analysis. These were later coded for the subsequent analysis through an extensive evaluation of individual transcripts which involved annotating them with notes and field reflections (Alvesson \& Skoldberg, 2000). The conversational style of informal, unstructured method of interviewing allowed a grasp of 'stories' people tell as they make sense of their personal experiences in relation to prevalent discourse(s) on a place. As Deleuze and Guattari assert:

"What matters is not ... the opinions held by characters in accordance with their social type and characteristics but rather the relations of counterpoint into which they enter and the compounds of sensations that these characters themselves experience or make felt in their becomings and their visions (1994, p. 188).

Thus with minimal prompt from the researcher, participants' narratives created a space within which it was possible to examine the "becomings and visions" (Deleuze and Guattari, 1994, p. 188) of the self (i.e. the narrator and the context within which s/he narrated their accounts). Overall, for most (54), visit to Scarborough was a regular feature as they either owned a caravan (10) or lived around 2-3 hours away from the town and were on a day out (29). Others were either visiting friends / family (9) or had business in the town (6) which included weekly shopping trip and appointment with the service providers (e.g. hairdresser, dentist, lawyer). The remaining six included in the sample were visiting from nearby towns of Whitby and Filey 
(4) and two leisure seekers lived in the vicinity, but who were insistent - "as much a visitor I am as any other bloke or lass you see here. .." (male, 50s). On the whole couples constituted $31 \%$ of the sample (over half were in their 50s or retired), $29 \%$ were on their own (but mostly accompanied by dogs) and the rest were families (40\%) who were interviewed as a group where members spontaneously contributed to the dialogue. It should be noted that it required great effort to solicit participants' support and input into the survey. Most did not want to be interviewed and the reasons for non-participation varied: they were 'just chilling out', 'doing nothing special', were 'local to the area ... have nothing much to say', '. . .running short of time' and one of the most amusing response was: 'no, thank you, I do not wish to be included in any prize draw if that is what you are after!'. On such occasions where it was difficult to elicit an extended response, I assumed the guise of a leisure seeker myself and by sharing my own experience at the beach and via participant observation I was able to gain an insight into how visitors are "affected by the place and its other occupants" (d'Hauteserre, 2015, p. 82). I now present the analysis which focuses both on individual subjectivity and collective becomings which actors work up in entrenching their attachment with the locality and the likeminded others and enacting re /deterritorialising flights to form new assemblages and social codes.

\section{Discussion and Analysis}

\subsection{Narrating Identity}

The beach is as Obrador-Pons (2007) suggests "first and foremost a haptic geography" (p. 134). Touch', the author argues "often exceeds the rational and the visual" (p. 135). Indeed, I observed from participants' accounts how the beach became a 'container' of disremembered identity by providing the sensual contact with other bodies, familiar food and the typical feeling of sun and sand on the skin, all of which acted as triggers in evoking elapsed memories.

"Scarborough has nothing much to offer for someone like me who is well travelled, but the endless beers, slapstick humour and the familiar okee dokee pats you share with your mates ... I mean I am a totally different person" (Male, 50s on a weekend break with friends).

The camaraderie and the caress accompanied with the familiar ring of 'okee dokee' embodies memories that are unavailable to vision. In fact, , the smooth space of the beach embodying constantly mobile entangled flows and ruptures or lines of flight affords the opportunity to a multitude of bodies to become $\mathrm{BwO}$ through being:

". . a part and parcel of our life ... We are an island nation. When it is warm and nice, instinctively you want to be on the beach ... like crabs crawl on the sand and love the feeling. You are doing the same thing like others - soaking up the sun, in that you are no different and yet you have your own little space and people respect that. I suspect that comes from living so close to your neighbours and yet you are never really in each other's face. I have done it countless of times and still never tire of it" (female 70s, on a weekend break from Doncaster).

In thus 'doing' the beach, seemingly unconnected life-worlds of beach users coalesce as their bodies blend, emulsify and dissolve into each other, producing in the process, what Huijbens (2013) calls "a new body-world" (p. 196) embodying "., , the infinite multiplicity and ongoing (un)making of any landscape via social and material relations. Indeed, beaching offers means 
to rearticulate and reimagine the specificities and potential of the body as is evident from this account:

"For me, beaching is more of a time I spend with my wife and dog watching the waves and the sun go down slowly something that takes you away from routine. But you witness some bizarre scenes as well. The other day I saw a group of young girls practicing acrobatics on the beach and before that someone singing their heart out with no care in the world. And then there are the dog walkers, people like me . . you don't know these people and yet in a funny way, you do ... (smiles)" (male, 50s, lives in the vicinity, walking his dog).

This narrative ties in with Lingis (1994) who underlines how travellers communicate their identity in relation to each other, using fellow voyagers as props in their narration of self. Also, such watchful attention, from the mobile perspective of this beach-user, brings to visibility a multiplicity of sites and micro-happenings beneath the surface underlining that:

“. . . territory is always an assemblage made up of many elements, many perspectives, many stories - and at times the lines shift, sprout connections, move in unpredictable ways, edges open out and territories change, possibility blossoms" (Instone, 2010, p. 373).

Indeed, the affective assemblage of beaching bodies not only affords an insight into the collage of subjectivities variously experienced and negotiated, but as an act of deteritorialisation, celebrates irrationalities and idiosyncratic allegiances amongst disparate actors. Yet, it also underlines that there is a lack of communal feeling of connectedness without seeing who is doing what which provokes both censure and approval. For instance, the assemblage of dogwalking space is supple and always subject to clefts as the rules by which dog walkers occupy shared spaces are continually in flux, fragile and dynamic (Pemberton, 2017). Whilst the dog acts as "a form of social lubrication" (Scott-Ordish $(1982,52)$ for people start to talk to the dog first before conversing with owners who are complete strangers, Pemberton alludes to the eruption of 'dog wars' over dog-faeces that are interpreted and contested as 'matter-out-ofplace'. Thus the degree of warmth and the 'insider status' dog-walkers accord to similar others is a negotiated deal dependent on animal behaviour. Thus owners with free running, uncontrolled animals are perceived as more likely to perpetuate vandalism, disruption and aesthetic harm, whilst I noticed smiles readily exchanged with the ones who possessed cutelooking, well-behaved animals on leash .

Thus the beach is not always a smooth and deterritorialised space. Molar lines do crisscross to sediment and bind actors (see Holford et al., 2013) as leisure sites like the beach become means to cement tacit leanings towards particular groupings (D'Andrea 2006; Saldanha 2007). "Familiarity" is, as Prasad (2012) claims, is relational emerging from encounters ... seeing one's affectations in others and vice versa" (p. 352).

For instance, ". . . being of the same colour helps", as this visitor pointed out:

'It does not feel like I am on a holiday. It takes a lot of effort to fit in . . . being of the same colour helps .. Most of the time people are good natured and do not bother, but you have to watch your step" (Asian Male, 40s, visiting with his partner from Leeds).

The intimate account of how this visitor made little attempt to reduce his distance from whiteness was not gathered off chance, but through a conscious effort on my part to make whiteness more visible by sharing my own experience of how I confronted whiteness in my 
everyday life. Thus I explained that although I lived locally in Scarborough, I was acutely aware of my 'outsider' status, of how I downplayed it by embracing my hybrid identity which was a rich mosaic of disparate cultural influences, but was "neither this nor that". Yet, as the research progressed, I was conscious, as Prasad (2012) reports: “. . . how my position as a researcher and an Indian ... limited my access to certain circles. The degree to which I was allowed into smaller cliques in the tourist milieu reflected the range of roles I could occupy. There were many that I could not access at all” (p. 371). This is in line with Lobo's (2014) work who points out that:

“. . . whiteness as a force . . . exerts affective pressures on bodies of colour who are hypervisible in public spaces . . . these pressures have the potential to wound, numb and immobilise bodies affecting what they can do or what they can become" (p. 101).

Saldanha $(2002 ; 2005)$ makes a comparable point in his work on Goa where he notes friction between white bodies that dance, sway to the music and the non-white ones that don't because of convention, individual disposition or because of the way the setting is arranged to omit their entry. Thus the beach offers to some, as Munt (2015) says, “. . . metaphors of escape. To others, it is a place to escape from .." (p. 12). The means by which this escape is achieved is via several intensive lines of flight that have the potency to empty the body of the influence of the strata (Markula, 2006). Thus the process of 'watching your step' also holds the possibility of traversing a different route and using that space to transgress set notions associated with what bodies of colour can do.

\subsection{Re(assembling) the Place}

According to Holford et al. (2013) bodies have the capacity to enact multiple becomings and are capable of interminable creative agency and "ways of being otherwise" (p. 714). These offer means of escaping from the fixities of (e.g. white) assemblages on the beach. Like the perimeter of the body's organs, each sub-assemblage of leisure seekers represents the simultaneous culmination / beginning of new lines of flight. Thus for some coming to Scarborough is a 'compulsion' as overseas visits are no longer affordable:

"Last time we went to Turkey cheap way of course, but by the time you have added up all the little extras, I remember it ended up costing us in excess of $£ 3000$ for a family of four . . you are compelled to stay put. Mind you, it is a beautiful part of the world, but I would prefer to go somewhere warmer if I could" (Male, 50s, cab driver from Rotherham).

To others, "the icy cold coast" is entangled with enhanced bodily sensations - "coming alive" (Male, 60s); "it's just like old days when I came here with mum and dad in 1990s" (Female, 50s); "on a day like this [i.e. sunny and warm] you close your eyes and shut out the world, you are in your little cocoon ... you feel safe"- providing scope for deterritorialisation. The ability of the family holiday to create this 'cocoon-like' affective space' ties in with Obrador's (2012) conceptual framing of coastal destinations as containers of thick sociality and relations of domesticity inducing feelings of belonging, desire and intimacy. Thus tourism is not always about escaping home, but about cultivating home-like space through travel and displacement by mobilising cherished and complex spatial imaginaries. 
In comparison, the sub-assemblage of adventure-seeking surfers, who are regarded as inhabiting "a world of their own" (female, 50s), is in stark contrast to the molarity of passive leisure seekers:

"We are not what you would term 'normal'. . I rather like being in the water than out of it and since I have much to learn, for most part I like to be left alone" (young surfer, male, 20s).

Hence surfers like him enact 'selfhood' that is in contrast to what they perceive as 'normal' routines and subjectivities of other leisure seekers and visitors as they (re)claim the coast through the smooth space of their surfing sphere which they traverse both singly and collaboratively "without aim or destination" (Deleuze \& Guattari, 1987, p. 389). Also, in the process of becoming (an expert) surfer, they are "becoming-undone" (Clark/Keefe (2014, p. 120). The state of 'becoming undone' is achieved when in the process of perfecting a craft (i.e. surfing), a coming together of intensities induces new meanings visitors derive from being in a place.

It also implies that surfers' assemblage, in contrast to dog-walkers, birds / waves' watchers, anglers and bodies "just chilling out" (male, 50s), convey discrete sense of purpose and capacity to produce "blocs of sensation" (Deleuze and Guattari, 1994, p. 164) that engender deterritorialising lines of flight. In fact, their leisure-seeking, characterised by perpetual movement and fluidity, both privileges and marginalises them. On one hand, they are able to employ the agency of their fit bodies to mobilise an almost utopian space of belonging and entrench their claim on the leisure space in the face of competing experiential groups. On the other, their bodily affects, perceived as impeding and interrupting the flows and desires of other bodies, provoke censure:

"They don't care much for dogs, children or other people" (Female, 60s, a regular dog walker on the North Bay).

Yet, like the arteries and veins that connect the organs to particular parts of the body, each subassemblage is tied to others and coexists through challenging, resisting and splintering in contingence and through their interdependence, time-worn sedimentaries. The contention here is that the beach environment, servicing and supporting the needs of leisure seekers, provides a space for new becomings that subvert how it was previously characterised. For instance, the 'aestheticisation process' of the coast, exemplified by events and activities (not traditional to the area), has set off the (re)assembling of the place through an unfixing of rooted practices and markers. Thus the sub-assemblage of the surfers has conjoined with other beach users in the Big Spring Beach Clean initiative to tackle the growing tide of marine litter (Haywood, 2014). Writing on the Daily Mail website - Mail Online - travel writer Rebecca English reports:

“. . . there's nothing Scabby about Scarborough". . . times are changing and a more genteel side to this largest and most popular holiday destination on the Yorkshire coast has started to bring back tourists en masse (TSN, 2012).

Indeed, the annual Seafest Maritime Festival - (initiated in 1998 and organised by Scarborough Borough Council in partnership with the Seafest steering group and cultural development 
agency, Create) - is emblematic of the 'changing times' and the coming together of a multiplicity of distinct elements - live music, cooking demonstrations, maritime, heritage and fireworks displays (www.discoveryorkshirecoast.com/scarborough/event/mainevents/scarborough-seafest). However, it is not only the epiphenomenon of planned events like these that allow body to experience inimitable connections with the place, but also the familiar and the mundane place attributes as this visitor highlights:

"Part of the town's charm has been its ability to stay the same. I hated it when growing up because of the same old things: fish \& chips, donkey rides, 'behind the times' feel and the sea-gulls! (laughs). I love it for these very things now that they are missing from my life. It is funny how human brain works: the once ordinary things become magical!" (Female, late 40s, visiting from London).

This (re)imagining and the (re)assembly of the place is possible as Lynch's (1976) work on places, identity and time and Sacks' (1995) on memory points out how sites, as containers of particular affects and assemblages of desires, semantically and ontologically, reconfigure into means of bringing about nonstratified, boundless state of becoming. Also, sensory and environmental cues conveyed in this visitor's account underline the incongruent manner in which the leisure seekers approach the beach and either transcend or cement molar norms. This in turn provides an analytical framework for rethinking the role of what Pearce (1988) calls the ordinariness of holiday experience.

\subsection{BwO and bodies' affective capacities}

The dynamism inherent in $\mathrm{BwO}$ as the site of resistance and refusal, being re / de territorialised continually, offers means to capture both the lived experiences bodies undergo and their reflexive selves embodying sensory meanings that have the potential to upstage normative patterns of leisure-seeking (territorialisations) as they interpret and (re)make a place according to their liking. As Gunn (2016) states,

"... the $\mathrm{BwO}$ both calls attention to the ways individuals are hierarchically organised into unified, categorisable subjects, and offers tools through which to challenge, even transgress, this organisation" p. 185).

From the accounts presented, it is clear that there is no singular positioning that can explicate bodies' affective capacities and in particular the 'flows' and intensities in which they consume a locality. Given the mobile and contested meanings of place participants offer, experiencing the coast can be regarded as rhizomatic voyaging replete with scepticism, reflection and meandering that presents interesting interludes bringing forth a relational field through which actors and landscape are mutually constituted.

In my understanding, spatial movement is not enough or the key prerequisite for acquiring new becomings, but it is by acquiring $\mathrm{BwO}$ or letting go of the strata and become malfunctioning desiring-machines that one can experience disparate rhythms and deterritorialising lines of flight. From this perspective, it makes sense to define and determine consumption routines not by essential conceptions of gender, age or occupation, but by unfolding and mutant flows and intensities. This calls for an abandonment of typologies as they are inherently fixing and an incorporation of myriad affects or forces ". . o of biology, of 
environment, of culture and reflexivity and of the aspirational potential which all living things possess ... defining (constraining, elaborating) the body's relations or affects ... [that $]$ together constitute the becoming-body ...” (Fox, 2002, p. 356). Importantly,

"Asking the question of a body: what can it do? (which are its relations?) informs us about its BwO (the confluences of a body with its affects and relations) .. . about deterritorialisation and lines of flight (the trajectories which open up possibilities for becomingother)" (ibid).

From a marketing perspective, both the theoretical significance and a practical utility of this proposition lies in the basis it provides for approaching place branding from an affective stance embodying consumers' aspirations by “opening-up to difference, to possibility and to the 'rightness' of the many rather than the few or the one" (Fox, 2002, 359). The beach offers an opportunity to examine how leisure spaces are experienced and co-created by users according to their preferences as they impose their conceptions (i.e. their gaze) to both regulate physical, social and moral behaviour and employ lines of flight (Deleuze and Guattari, 1988, p. 9) by which the $\mathrm{BwO}$ escapes from territorialisations. In considering collectives of bodies and their affective capacity to create places, this work invites practitioners to engage with nuanced understandings of tourists' experiences and their role in the co-creation of behaviours and practices at destinations (d'Hauteserre, 2015).

\section{Conclusions}

Theoretically, the value of this paper lies in its examination via $\mathrm{BwO}$ of the micro spatial tactics that actors employ to create hybrid leisure spaces and enact them through mutually negotiating the use of space. For practitioners, this study has shown how the reading of $\mathrm{BwO}$ as "a continuum of all substances in intensity and of all intensities in substance" (Deleuze and Guattari (1987, p. 166), can be employed to deterritorialise the place from strata and engage with the desires and flows inherent in different assemblages to enliven it. Thus one key area of future investigations is to assay how to construct a BwO by fitting together leisure-seekers' desires / practices with place semiotics to enable branding strategies to reflect the imaginative and playful elements inherent in their agency. A distinctive advantage of using Deleuze and Guattari's work is their ontology of becoming which provides means to move beyond the binaries - passive / active leisure seekers, good / bad visitor behaviour, male / female groupings and instead focus on flows, desires and intensities that make it possible to view identities as malleable and their (re)workings of the place as interminable.

Overall, the contribution of this work to tourism and management studies is two-fold. First, it seeks to address what Korczynski and Ott (2004) regard as “. . . a frustrating dearth of a critical research . . . in which the voices of customers are present” (p. 594). By focusing on visitor voices in the analysis, this investigation offers a detailed appreciation of their 'vision' of value which they derive in particular settings. Case lessons can inform both the development of competencies and differential positioning centered on these values and marketing tactics designed to accentuate users' sense of affinity with a place. Secondly, it sheds a critical and analytical light on how visitors enact their sociality in a leisure space by focusing on their bodies' affective capacities which calls for a re-thinking of tourism/tourists/leisureseekers, and their indeterminate, multiple sensibilities. This is an area which has remained 
traditionally neglected in tourism marketing and management research, particularly the focus on how "a body affects other bodies, or is affected by other bodies" (Deleuze, 2005, p. $58)$.

Further research (especially survey and experimental studies) is needed to systematically build and test the link between bodily affects and visitors' agency. A key limitation of this study lies in its omission of voices of those with disabilities and the constraints / affective capacities they experience. Since people with disabilities constitute a large market segment considering that $70 \%$ of Europe's population with accessibility needs amounting to 97 million people have both the financial and physical capacity to travel (see CBI, 2015), it is a significant area of research.

In closing, I reiterate that employing $\mathrm{BwO}$ as a theoretical tool has allowed me to move away from the research looking at leisure-seekers' sociality from the angle of static, visible representations of their bodies and behaviour. Instead, I engage with visceral, ephemeral movement of their enterprise that ushers in distinctive yet transitory synergies in a place because:

"You never reach the Body without Organs ... you are forever attaining it, it is a limit. People ask, So what is this $\mathrm{BwO}$ ? - But you're already on it, scurrying like vermin, groping like a blind person, or running like a lunatic: desert traveller and nomad of the steppes. On it we sleep, live our waking lives, fight - fight and are fought - seek our place, experience untold happiness and fabulous defeats; on it we penetrate and are penetrated; on it we love" (Deleuze, 1987, p. 150).

Indeed, visitors construct particular roles for themselves in a leisure setting and entrench their ties with one or several of other groupings, self-categorise, but once claiming a particular status, associate themselves with other social entities in an attempt to accomplish "not just one of the crowd' status. Thus this study not only contributes to growing body of work on "the affective field of destinations" (Jóhannesson and Lund, 2017, p. 189), but serves as a call for a rethinking of tourists / leisure-seekers' subjectivities and their arbitrary energies and countercultures that do not belong to pre-set categorisations, but are co-constructed at least in part as they are entangled together. 


\section{References}

Alvesson, M., \& Skoldberg, K. (2000). Reflexive methodology: New vistas for qualitative research. London: Sage.

Bazzul, J. \& Kayumova, S. (2016).Toward a Social Ontology for Science Education: Introducing Deleuze and Guattari's assemblages. Educational Philosophy and Theory, 48(3), 284-299.

Biehl, J. \& Locke, P. (2010). Deleuze and the Anthropology of Becoming. Current Anthropology 51(3), 317-351.

Boorstin, D. (1964) The Image. New York: Harper \& Row.

Canniford, R. (2011) How to manage consumer tribes, Journal of Strategic Marketing, 19(7), 591-606.

CFE (2015). Scarborough: Rebranding Britain's most traditional seaside resort. Centre for Entrepreneurs (CFE), September 29, http://centreforentrepreneurs.org/scarboroughrebranding-britains-most-traditional-seaside-resort/ accessed 04/05/16

Cherrier, H. (2007). Ethical consumption practices: Co-production of self-expression and social recognition. Journal of Consumer Behaviour, 6, 321-335.

Clark/Keefe, K. (2014). Becoming artist, becoming educated, becoming undone: toward a nomadic perspective of college student identity development, International Journal of Qualitative Studies in Education, 27:1, 110-134.

Collier, S. J. \& Ong, A. (2005). Global assemblages, anthropological problems. In Ong, A. \& Collier, S. J. (ed.) Global assemblages: technology, politics, and ethics as anthropological problems, 3-21. Malden, MA: Blackwell.

Cull, L. (2011). Attention Training Immanence and ontological participation in Kaprow, Deleuze and Bergson. Performance Research, 16(4), 80-91.

Deleuze, G. (2006). Two regimes of madness: texts and interviews 1975-1995. Los Angeles: Semiotext(e).

Deleuze, G. (2005) Ethology: Spinoza and us, in Fraser,M. and Greco, M. (eds) The Body: A Reader. London: Routledge, pp. 62-66.

Deleuze, G. and Guattari, F.L. (1994), What is Philosophy? New York, NY: Columbia University Press.

Deleuze, G. (1993). What is Becoming? The Deleuze Reader. ed. Constantin V. Boundas. New York: Columbia University Press.

Deleuze, G. (1991). Bergsonism (trans. H. Tomlinson and B. Habberjam). New York: Zone Books. 
Deleuze, G. (1990/1969). The Logic of Sense, ed. Constantin V. Boundas, trans. Mark Lester with Charles Stivale. London: Athlone.

Deleuze, G. (1990). What Can a Body Do? in Expressionism in Philosophy: Spinoza. New York: Zone Books.

Deleuze, G. (1988). Spinoza. Practical Philosophy. San Francisco, CA: City Lights Books.

Deleuze, G. \& Guattari F. (1987). A Thousand Plateaus: Capitalism and Schizophrenia Translated by Massumi, B. Minneapolis: University of Minnesota Press.

Deleuze, G. \& Guattari, F (1984/1972). Anti-Oedipus: Capitalism and Schizophrenia Vol. 1. Trans. R. Hurley, M. Seem \& H. R. Lane. London: Athlone.

Deleuze, G. \& Guattari, F. (1977). Anti-Oedipus. Capitalism and Schizophrenia. (Trans. Robert Hurley, Mark Seem \& Helen Lane). New York: Viking Press.

Deleuze, G. \& Parnet, C. (1987). Dialogues (trans. H. Tomlinson and B. Habberjam). London: The Athlone Press.

Fox, N. J. (2002). Refracting 'health': Deleuze, Guattari and body-self. health: An Interdisciplinary Journal for the Social Study of Health, Illness and Medicine, 6(3), 347-363.

Franklin, A. \& Crang, M. (2001). The trouble with tourism and travel theory? Tourist Studies, $1(1), 5-22$.

Garoian, C. (2013). The prosthetic pedagogy of art. New York: The State University of New York.

Haines, C. (2011). Corporeal Time, Angelaki, 16(2), 103-126.

Haldrup, M. \& Larsen, J. (2003).The family gaze. Tourist Studies, 3(1) 23-45.

Hansen, J. (2010). Becoming a body without organs through Tuba performance. Perspectives of New Music, 48(1), 83-91.

Haywood, J. (2014). Surfers in Scarborough join the Big Spring Beach Clean campaign. Yorkshire Life, February 21, http://www.yorkshirelife.co.uk/outabout/places/surfers_in_scarborough_join_the_big_spring_beach_clean_campaign_1_334200 2 , accessed 09/06/16.

Hazbun, W. (2010). Modernity on the beach: A postcolonial reading from southern shores. Tourist Studies, 9(3), 203-222.

Hough, E. (2011) Rethinking authenticity and tourist identity: expressions of territoriality and belonging among repeat tourists on the Greek island of Symi, Journal of Tourism and Cultural Change, 9:2, 87-102 
Hughes-Morgan, M. (2009). How Scarborough is shaking off its down-at-heel seaside image and wooing a new breed of buyer. June, 11, http://www.dailymail.co.uk/property/article1192412/How-Scarborough-shaking-heel-seaside-image-wooing-new-breed-buyer.html, accessed 1/12/16.

Huijbens, E. H. (2013). Inspiring the visitor? Landscapes and horizons of hospitality. Tourist Studies, 13(2), 189-208.

Instone, L. (2010). Walking towards Woomera: touring the boundaries of 'unAustralian geographies'. Cultural geographies, 17(3), 359-378.

Jackson, A. Y. (2010). Deleuze and the girl. International Journal of Qualitative Studies in Education, 23(5), 579-587.

Jóhannesson, G. \& Lund, K. An. (2017). Aurora Borealis: Choreographies of darkness and light. Annals of Tourism Research 63, 183-190.

Korczynski, M. \& Ott, U. (2004). When Production and Consumption meet: cultural contradictions and the enchanting myth of customer sovereignty, Journal of Management Studies 41(4), 575-599.

Kotler, P. (1986). The prosumer movement: A new challenge for marketers. Advances in Consumer Research, 13, 510-513.

Li, T. M. (2007). Practices of assemblage and community forest management. Economy and Society, 36(2), 263-293.

Lingis, A. (1994). Abuses. Berkeley, CA: University of California Press.

Little, K. (2010). Paradise from the other side of nowhere: troubling a troubled scene of tourist encounter in Belize, Journal of Tourism and Cultural Change, 8(1-2), 1-14.

Lobo, M. (2014). Affective energies: Sensory bodies on the beach in Darwin, Australia. Emotion, Space and Society, 12, 101-109.

Löfgren, O. (1999). On Holiday: A History of Vacationing. Berkeley: University of California Press.

Lynch, K. (1976). What time is this place? Cambridge. Mass.: MIT Press.

Malins, P. (2004). Machinic assemblages: Deleuze, Guattari and an ethico-aesthetics of drug use. Janus Head, 7 (1),84-104.

Markula, P. (2006). The Dancing Body without Organs: Deleuze, Femininity, and Performing Research. Qualitative Inquiry 12 ( 1), 3-27.

Massumi, B. (1992). A User's Guide to Capitalism and Schizophrenia: Deviations from Deleuze and Guattari. USA: Massachusetts Institute of Technology. 
Matteucci, X. (2014). Forms of body usage in tourists' experiences of flamenco. Annals of Tourism Research, 46, 29-43.

Mostafanezhad, M. (2016). Volunteer Tourism: Popular Humanitarianism in Neoliberal Times. London: Routledge.

Mowforth, M. \& Munt, I. (2009). Tourism and Sustainability. London: Routledge.

Mullarkey, J. (2006). Post-Continental Philosophy: An outline. London and New York: Continuum.

Munt, S. R. (2015). Sensory geographies and defamiliarisation: migrant women encounter Brighton Beach, Gender, Place \& Culture, 1-11.

Obrador-Pons, P. (2012). The place of the family in tourism research: domesticity and thick sociality by the pool. Annals of Tourism Research, 39(1), 401-420.

Obrador-Pons, P. (2007). A haptic geography of the beach: naked bodies, vision and touch, Social \& Cultural Geography, 8(1), 123-141.

Obrador-Pons, P. (2003). Being-on-holiday: Tourist dwelling, bodies and place. Tourist Studies, 3(1) 47-66.

Ong, A. and S. J. Collier (2004). Global Assemblages: Technology, Politics, and Ethics as Anthropological Problems. London: Blackwell.

Ourahmoune, N. (2016). Narrativity, temporality, and consumer-identity transformation through tourism. Journal of Business Research, 69, 255-263.

Patton, M. Q. (2002). Qualitative research and evaluation methods (3rd ed.). Thousand Oaks, CA: Sage.

Pearce, P. (1988). The Ulysses Factor: Evaluating Visitors in Tourist Settings. New York: Springer Verlag.

Pearce, P. (1982). The social psychology of tourist behaviour. Oxford: Pergamon Press. Pemberton, N. (2017). The Burnley Dog War: The Politics of Dog-Walking and the Battle over Public Parks in Post-Industrial Britain. Twentieth Century British History, 28(2), 239-267

Poon, A. (1993) Tourism, Technology and Competitive Strategies. Oxon: CABI

Prasad, P. (2012). The baba and the patrao: negotiating localness in the tourist village. Critical Arts, 26(3), 353-374.

Renold, E. \& Ringrose, J. (2011). Schizoid subjectivities? Re-theorizing teen girls' sexual cultures in an era of 'sexualization'. Journal of Sociology, 47(4), 389-409.

Richards, G. \& Marques, L. (2012). Exploring Creative Tourism: Editors Introduction. Journal of Tourism Consumption and Practice 4(2),1-11. 
Ringrose, J. (2011). Beyond Discourse? Using Deleuze and Guattari's schizoanalysis to explore affective assemblages, heterosexually striated space, and lines of flight online and at school, Educational Philosophy and Theory, 43(6), 598-618.

Ringrose, J. \& Renold, E. (2014). "F**k Rape!": Exploring Affective Intensities in a Feminist Research Assemblage. Qualitative Inquiry, 20(6) 772-780.

Sacks, O. (1995). An anthropologist on Mars. Sydney: Picador.

Saldanha, A. (2007). Psychedelic white: Goa trance and the viscosity of race. Minneapolis: University of Minnesota Press.

Saldanha, A. (2005). Trance and visibility at dawn: racial dynamics in Goa's rave scene. Social \& Cultural Geography, 6(5), 707-721.

Saldanha, A. (2002). Music tourism and factions of bodies in Goa. Tourist Studies, 2(1) 4362.

Saxena, G. (2015). Imagined relational capital: An analytical tool in considering small tourism firms' sociality. Tourism Management, 49, 109-118.

SBC (2011). Scarborough Borough Tourism strategy (2011-2014). Scarborough: Scarborough Borough Council.

SBC (2005). Scarborough Growth Potential Study: Final Report. Scarborough: Scarborough Borough Council.

Scarborough (2015). Boost in visitor numbers and spend. July 27, http://www.scarborough.gov.uk/latest-news/boost-visitor-numbers-and-spend, accessed 4/05/16.

Scott Ordish, L. (1982), House of Commons transcripts, BLA 5(65), 52.

Thrane, C. \& Farstad, E. (2011). Domestic tourism expenditures: the non-linear effects of length of stay and travel party size. Tourism Management, 32(1), 46-52.

Thrift, N. (2008). Non-representational theory: Space, politics, affect. London: Routledge.

Thrift., N. (2004). Intensities of feeling: Towards a spatial politics of affect. Geografiska Annaler, $86 B(1), 57-78$.

TSN (2012). Scarborough is winning more praise from travel writers in the national press. The Scarborough News, March 30, http://www.thescarboroughnews.co.uk/news/business/highpraise-indeed-for-tourist-haven-scarborough-1-4402151, accessed 10/06/16.

TSN (2010). Scarborough's beach is still a mess. The Scarborough News, April 30, http://www.thescarboroughnews.co.uk/news/local/scarborough-s-beach-is-still-a-messcomment-on-this-story-1-1474501, accessed 11/ 05/16. 
Tuck, E. (2010). Breaking up with Deleuze: desire and valuing the irreconcilable. International Journal of Qualitative Studies in Education, 23(5), 635-650.

Vainikka, V. (2013). Rethinking Mass Tourism. Tourist Studies, 13(3), 268-286.

Veijola, S. Molz, J. G. Pyyhtinen, O. Höckert, E. \& Grit, A. (2014). Disruptive Tourism and Its Untidy Guests: Alternative Ontologies for Future Hospitalities, UK: Springer.

Waitt, G. \& Duffy, M. (2010). Listening and Tourism Studies. Annals of Tourism Research, $37(2), 457-477$.

Young, M. (1999). The Social Construction of Tourist Places, Australian Geographer, 30(3), 373-389.

YPE (2015). Welcome to Yorkshire reveals the £50m impact of the first Tour de Yorkshire race. Yorkshire Evening Post, 13 November, http://www.yorkshireeveningpost.co.uk/news/welcome-to-yorkshire-reveals-the-50m-impactof-the-first-tour-de-yorkshire-race-1-7570367 accessed 08/05/16. 